\title{
THE ROLE OF STUDENT SELF-GOVERNMENT IN ENSURING THE QUALITY OF HIGHER EDUCATION
}

\author{
OKSANA KONDUR, NATALIIA KOTURBASH, GALYNA MYKHAYLYSHYN
}

\begin{abstract}
The current state of development of the Ukrainian state requires further reform of all spheres of life of the Ukrainian community. The democratization of the principles of higher education needs special attention. Since students are the driving force of society, the developer of unique ideas of the present and future, a factor in the formation and development of civil society, so the democratization of student life, active participation of students in different organizations, leadership skills and teamwork, making the right decisions and responsibility for their implementation becomes especially relevant during educational transformations.

Student governments have a significant impact on youth. The range of such influence primarily extends to the realization of the student in the modern world, meeting his/her needs, both in education and in other areas, including volunteer, artistic, managerial, social and more. Therefore, membership in student organizations gives a young person a valuable life experience, which can later be implemented in practice. Participation in student self-government contributes to the development of students' leadership qualities, the formation of their active civic life positions. That is, the activities of student government in higher education institutions are aimed at forming the values of the younger generation.

At the same time, student self-government is a unique factor in reforming the modern system of the educational process in higher education institutions. Applicants are actively involved in the development, implementation, and accreditation of educational programs, are experts in the accreditation of the National Agency for Quality Assurance in Education. The article demonstrates the effectiveness of student self-government bodies in higher education institutions on specific examples, substantiates the need for their development as one of the factors that contributes to the improvement of quality assurance processes in education.
\end{abstract}

Keywords: student self-government, educational process, quality of education, higher education, leadership.

\section{INTRODUCTION}

In the conditions of democratization of society and Ukraine's accession to the European Union, the problems of educating a new type of managers who would not so much give orders as they were able to organize, lead and inspire employees are becoming more and more important. In the first place in the field of management there are issues of improving the level of managerial competence and organizational skills of managers in all spheres of life, as the struggle for quality becomes more significant. One of the factors that contributes to the formation of the foundations of the managerial 
culture of the youth is the participation in the work of student self-government bodies while studying at a higher education institution (HEI).

The relevance of the study of the role of student government in HEI is due to the following reasons:

- there is an active establishment of democratic principles in all sectors of Ukrainian society;

- democratization in the field of education continues according to the principles of the Bologna process, according to which students are considered as a subject of the educational process;

- students are always «indicators" of the socio-economic and political state of society, because young people are the least conservative in their values, the most sensitive to social changes, react sharply to violations of democratic norms, laws, moral principles;

- student government is an important factor in identifying potential leaders, developing their skills of management and organizational work with the team, the formation of the future elite of the nation [14].

\section{ANALYSIS AND DisCUSSION}

The main objectives of our study are to identify the essential and functional features of student government, its role in the structure of HEI; disclose of the significance of its activities on the example of the organization of the work of student self-government bodies.

The foundations of personal perception of the world around the child are laid by the family and school, but the final formation of personality occurs in the student years. Students determine the intellectual and cultural level of any state at any stage of its formation [2, p. 8].

Self-government is interpreted by researchers as: a form or process of organizing the life of members of the educational team (Yu. Tikhomirov, V. Gurov, V. Grekhnev); method of team selforganization (A. Shchaglyk, V. Korotov); method of involving team members in management activities (V. Slastyonin); the principle of team organization (Z. Bilousova, N. Kuzmina); means of educating the individual, a factor in its comprehensive development (T. Butkivska, A. Kyrychuk, S. Karpenchuk) $[12$, p. 7].

Researcher I. Yanyschuk considers student self-government as a system-integral formation with its inherent qualitatively new characteristics. The purpose of creating such a system is primarily the socialization of the personality of the future specialist, the definition of moral guidelines. The systematic approach to the organization of student self-government is characterized by the coverage of the spheres of life of HEI - the educational process, research activities, sports and health activities; problems of student life and leisure; participation of students in the public life of the city, community, state - and extends to all levels of the academic community [17, p. 215].

According to V. Prykhodko, self-government in HEI is an independent public activity of students in the implementation of the functions of HEI management, which is carried out by students in accordance with the purpose and tasks facing the student body. It is in the activity of student selfgovernment that the laws of management and regularities of education acquire a special, peculiar specificity [2, p. 14].

Self-government is one of the forms of "democracy" - a kind of method of governance, which is based on organization, self-regulation and initiative, does not allow the use of a special apparatus of coercion. Student self-government in HEI can be considered not only as a tradition, but also as a mechanism for building a model of management education in general and a way to establish democratic principles of the future elite [16, p. 30].

Students are full partners in the management of higher education. In Ukraine, the legal basis for the functioning of student government is the following regulations: Law of Ukraine "On Education" [8], which sets out the definition of bodies and rights of public self-government; Law of Ukraine "On Higher Education" [9]; Regulations of student self-government of the university, which is approved at the meeting of the student body of each university.

According to Article 40 of the Law of Ukraine "On Higher Education" [9] the main tasks of student government are: 
- ensuring and protecting the rights and interests of students, in particular, in relation to the organization of the educational process;

- ensuring that students perform their duties;

- promotion of educational, scientific and creative activities of students;

- promotion of the creation of appropriate conditions for living and recreation of students;

- promotion of the activities of student groups, societies, associations, clubs of interest;

- organization of cooperation between students of other higher educational institutions and youth organizations; - promotion of employment of graduates;

- participation in solving issues of international student exchange [14, p. 8-9].

Participation in student self-government allows a young person to acquire management and organizational skills, learn to responsibly perform their duties and tasks. It promotes the establishment of constructive cooperation between students and the administration of HEI. Defending the interests of students, in particular in terms of ensuring the effective organization of the educational process, representatives of student government form much higher requirements for HEI and their employees, resulting in improving not only the teaching process, but also both its subjects.

Student government forms real leaders of society, the future elite of the nation; allows the student to be heard, creates opportunities for the realization of civic position, talents, stimulates the activity of young people in public life in general. Because "society's need for a new generation of leaders can be satisfied through student government as an active form of organization of life of students, contributing to the development of their autonomy in decision-making and responsibility for the results obtained in achieving socially and personally meaningful goals" [1, p. 2136].

Student self-government plays a decisive role as a factor in shaping the management culture of youth. In a broad sense, management culture is considered as an activity inherent in any person, regardless of profession. In the narrow - as a specific activity of the head, manager.

The concept of "management culture" is close to the concept of "culture of management", but they are not identical. The first characterizes the professional and personal qualities of the specialist, the second - the peculiarities of management. Management culture is an important prerequisite for culture of management, although scientists believe that such a distribution is relative [13, p. 31-32].

In the most general form, management culture can be defined as an integrated, complex in content, socially determined quality of the manager's personality, which synthesizes a significant number of professional and personal characteristics designed to actualize the practice of creative management to improve its efficiency, optimize the pedagogical process [10].

According to researchers I. Anosov, V. Prykhodko [2, p. 127-128], management culture is one of the fundamental spiritual needs of the individual, which arises in the process of spiritual-practical and transformative human activity and is associated with the intra-personal mechanism of regulation and self-regulation. It acts as an internal, subjective source of activity, which determines the process of assimilation of the current worldview in society, the transformation of the categories of responsibility for their actions in the concepts and images of their own beliefs.

Culture of management, according to V. Novoselov, is a set of requirements for the external side of the management process, as well as the personal qualities of employees who carry out this process [11].

Y. P. Kraschenko [7] defines the culture of management as a set of achievements in the organization and implementation of the management process, the organization of management work, based on the use of science and technology management, taking into account the needs of the management system, employees and due to norms and principles of humanistic morality, ethics, and law.

As we have mentioned, the basis for the effective formation of the student management skills is active participation in public life and student government. After all, this is where the first skills of teamwork and team building, organizing and conducting events (scientific, entertainment, cognitive, volunteer), the ability to plan time and actions, the ability to clearly set goals and find ways to achieve them, self-organization skills are formed.

Analysis of the development of student self-government in some HEI of Ukraine, highlighting the main problems of student self-government, taking into account the experience of different free self- 
government of HEI open opportunities to improve the structure of student self-government bodies in each HEI.

The Student Council ("Senat") is a real opportunity to gain experience in practical organizational and teamwork, meet a large number of young, active and interesting people from all over Ukraine, show abilities and to improve skills of the organization of various actions, try the possibilities of the head of projects, receive support and useful recommendations. One can be heard at the university, local, regional and state levels of youth policy, to participate in the development and submission of proposals to improve student life. And as a result, you can be noticed by the management of HEI, civil servants of various levels, businessmen and businessmen who are interested in active, energetic, young people.

We analyzed in detail the activities of the student self-government body of Vasyl Stefanyk Precarpathian National University (PNU) - the student "Senat" [15], which has been operating at the university since 2004. The organization includes representatives of all institutes and faculties that directly implement the activities in its educational unit and at the same time represent the interests of students at the university level. The organizational structure of the "Senat" is hierarchical, a kind of divisional structure, as local "senators" ("senators" of academic groups) quickly respond to students' requests.

The supreme body of this organization is the general meeting (conference), at which the Regulations on the Student "Senat" are approved, the executive body is elected, its structure and term of office are determined, and reports are heard.

The work of the PNU student "Senat" is organized at the level of faculties, departments, academic groups, and dormitories. The chairman of the student senate organizes the work of individual structural units, heads of departments are members of the Academic Council of the University, which discusses the activities of the student "Senat", problematic issues of student life.

The Student "Senat" has committees in the following areas of work: educational, scientific, cultural and educational, protection of students' rights, sports and health, social and household, and press center.

The main task of the HEI is to ensure the quality of training of highly qualified specialists, enterprising, ready to make and implement socially and collectively significant decisions. Active student government is involved in the development and discussion of curricula, because students have their own vision of opportunities to achieve excellence in education, which will develop critical thinking, decision-making skills and problem solving, so that students can all significantly contribute to the state-building process. Thus, at PNU the heads of structural subdivisions are members of the highest governing bodies of educational subdivisions - academic councils of faculties and institutes. At the meetings of the Academic Councils, the representatives of the Senate express their wishes regarding the modernization of the educational process.

An important factor in encouraging young people to join such organizations is the correct information policy, which is engaged in a separate committee of the Student "Senat" of PNU. In particular, it is the maintenance of sites, web pages on social networks (Facebook, Instagram), as well as Telegram and YouTube channels. It also affects the career guidance work of the HEI and the attraction of new students to it, because who can better advertise the student life of the entrant, than not yesterday's entrant, but the current student.

Members of the Student "Senat" are members of scholarship commissions. They also agree on the ranking of students in each specialty by course. As members of scholarship commissions, they have the right to approve or challenge students' recommendations for the award of scholarships by the Government of Ukraine or from various scholarship funds. In particular, representatives of student government participate in a closed evaluation of projects of students seeking to become scholarship holders of the Trust in Yourself Foundation. The Foundation is happy to finance the implementation of interesting projects of young people who come from the countryside and offer to develop rural communities, first of all - children and youth of these communities. 
One of the main functions of the student "Senat" is to protect the rights of students, the development of their organizational and managerial competence and leadership qualities. After all, for a modern young person «the lack of leadership abilities and skills should be considered as computer or any other illiteracy» [14, p. 16]. Participating in the activities of student government, the individual has a chance to develop leadership skills in management. For example, heads of departments monitor the teaching and learning process in order to help improve the quality of educational services for future professionals.

The leadership of the PNU "Senat" actively cooperates with other public organizations of the city and the country. In the near future there are plans to develop international cooperation with representatives of student government in European countries. This will be facilitated by the International Center for Youth Meetings of Ukraine and Poland, which is being built by PNU in the village of Mykulychyn in the Ivano-Frankivsk region with funding from the Ukrainian government. This center is a joint plan of PNU and the University of Warsaw. It is planned to focus its activities on the development of partnerships and cooperation not only between Ukrainian and Polish youth, but also among young people from other European Union countries.

"Student government is an integral part of higher education, the main task of which is to represent the interests of students. The scope of their activities is determined by the legislation and internal regulations of each free HEI" [4, p. 10]. The Student "Senat", as one of the organizational types of student self-government, is a mandatory part of HEI management system. The university management follows the student's inquiries and wishes. Meetings of the Rector with the student body in each HEI are traditional. In particular, the Rector of PNU, Professor Igor Tsependa, during the quarantine due to the pandemic, held a series of online briefings for students on current topics, including the work of the university in quarantine, new challenges due to distance learning, academic integrity in the forms of summative assessment.

The influence of students on the processes that contribute to ensuring the quality of education is constantly growing. In particular, after careful admission, students become experts of the National Agency for Quality Assurance in Education in Ukraine. In the future, they participate in the accreditation of educational programs of HEI throughout the country. This increases the objectivity of recognizing the adequacy of educational programs to the relevant state industry standards. At the same time, student-experts learn good examples of excellent organization of the educational process, realize the similarity of student problems, regardless of the field of knowledge to which the educational program belongs, or from a specific HEI. At the same time, there is a good practice of involving the student self-government asset, the educational unit in the accreditation processes. In particular, participation in meetings with experts, providing the student expert with detailed reliable information on the level of participation of students in the implementation and realization of the educational program in HEI.

\section{CONCLUSIONS}

In modern conditions, a young highly qualified specialist for successful integration into the rapidly changing business world must have experience in business activity, be proactive, responsible for both the individual area of work and the overall outcome of the case, be able to tolerate other people's ideas and at the same time convincingly defend their point of view in the team, be persistent and flexible to achieve the final result, have leadership qualities. Therefore, in addition to professional training, higher education should help young people get ready for today's challenges. This is a great help of student government. Involving as many students as possible in active student life, eradicating indifference to modernization of educational processes, their compliance with modern labor market requirements, both regional and global, adherence to the principles of academic integrity, cultivating needs and providing opportunities to learn about the benefits and problems of student life in others countries these are some of the important tasks of student government at the current stage of development of higher education. 
It is obvious that the intensification of student self-government participation in the processes of quality assurance of higher education requires appropriate training of students, namely the formation of managerial and qualification competence, which we described in detail in our other research $[3 ; 6]$.

\section{REFERENCES}

[1] Alimbekova A.A., Bakyt A.Zh., Kyyakbaeva U.K., Suranshieva M.K. Leadership Development University Students in the Activities of Student Government. Proceedings - Social and Behavioral Sciences, 197 (2015), 2131-2136. doi:10.1016/j.sbspro.2015.07.336

[2] Anosov I.P., Prykhodko V.M., Prykhodko M.I. Socio-pedagogical foundations of student self-government as a source of democratization of higher education (management aspect). LLC "Publishing House" MMD, Melitopol, 2008. (in Ukrainian)

[3] Budnyk O., Kondur O., Mykhaylyshyn G., Ridey N. Diagnosis of managerial and qualification competence of students in higher education institutions. Open educational e-environment of modern University. Special issue "New pedagogical approaches in STEAM education", (2019), 32-43. (in Ukrainian)

[4] Cseh G, Varga Z.K. The development of the situation of student governments in higher education, in particular the problems arising today. Miskolci Jogtudó, 3 (2020), 10-16. (in Hungarian)

[5] Gribovych A., Kondur O., Melnyk Y. Actualization of Leadership as a key category of neoeconomical community: socio-cultural and educational aspects. Journal of Vasyl Stefanyk Precarpathian National University, 6 (1) (2019), 50-59.

[6] Kondur O.S., Ridey N.M., Panchenko L.M., Sapiga O.P. Professional training of specialists in the quality of education in higher education. Postgraduate education strategy for sustainable development: monograph. MPU Publishing House. Dragomanova, Kyiv, 2020. (in Ukrainian)

[7] Kraschenko Y.P. Features of the organization of the student self-government system. The origins of pedagogical skills. Series: Pedagogical sciences, 6 (2009), 255-262. (in Ukrainian)

[8] Law of Ukraine "On Education": current legislation as of 05.09.2017. Available at: https://zakon.rada.gov.ua/laws/card/2145-19/. (in Ukrainian)

[9] Law of Ukraine "On Higher Education": current legislation as of April 3, 2014. Available at: https://zakon.rada.gov.ua/laws/show/1556-18\#Text. (in Ukrainian)

[10] Lucero J. Students' satisfaction on the supreme student government services: basic for action plan, 2021. doi: 10.13140/RG.2.2.26249.47200.

[11] Maxwell-Stuart R. The state of student governance in the commonwealth, 2016. Available at: https://mail.google.com/mail/u/1/\#inbox/QgrcJHrtvXXsFFnxWtScCqGSnfbcZBjhmtQ?projector=1\&mes sagePartId $=0.3$

[12] Potopa K.L. Socio-pedagogical conditions of the organization of student self-government in higher educational institutions. Author's ref. dis. for science. title of candidate ped. science. Kyiv, 2006. (in Ukrainian)

[13] Student government in Ukraine. "Youth Alternative", Kyiv, 2004. (in Ukrainian)

[14] Stepko M.F. (Ed.) Student self-government as an integral part of the democratization of higher education: Recommendations for conducting the first lecture in higher education. Knowledge, Kyiv, 2005. (in Ukrainian)

[15] Student Senate of Vasyl Stefanyk Precarpathian National University. Available at: https://senat.pnu.edu.ua/про-нас/. (in Ukrainian)

[16] Yaresko K.V. Culture of management of educational activity of students: monograph. KhNURE, Kharkov, 2004. (in Ukrainian)

[17] Yashchuk I.P. Optimization of student self-government bodies in higher educational institutions in the context of realization of ideas A. S. Makarenko. Origins of pedagogical skill, 4 (2008), 214-221. (in Ukrainian) 
Address: Oksana Kondur, Nataliia Koturbash, Galyna Mykhaylyshyn, Vasyl Stefanyk Precarpathian National University, 57 Shevchenko St., Ivano-Frankivsk 76018, Ukraine.

E-mail: oksana.kondur@pnu.edu.ua; nataliia.koturbash@pnu.edu.ua; galmuh60@gmail.com.

Received: 16.01.2021; revised: 17.03.2021.

Кондур Оксана, Котурбаш Наталія, Михайлишин Галина. Роль студентського самоврядування у забезпеченні якості вищої освіти. Журнал Прикарпатського університету імені Василя Стефаника, 8 (1) (2021), 65-71.

Сучасний стан розвитку української держави потребує подальшого реформування всіх сфер життедіяльності української громади. Своєрідної уваги потребує демократизація принципів вищої школи. Оскільки студентство є рушієм думки суспільства, розробником унікальних ідей сучасного та прийдешнього, чинником формування та розвитку громадянського суспільства, тому демократизація студентського життя, активна участь студентів в роботі студентських організацій, формування лідерських навиків та вміння працювати в команді, приймати правильні рішення та нести відповідальність за їх виконання набувають особливої актуальності під час освітніх трансформацій.

Органи студентського самоврядування мають значний вплив на студентство та молодь. Діапазон такого впливу насамперед поширюеться на реалізацію здобувача освіти в сучасному світі, задоволення його потреб, як в навчальному, так і в інших напрямках, зокрема у волонтерському, мистецькому, управлінському, соціальному тощо. Тому членство в студентських організаціях дає молодій людині цінний життевий досвід, який вона пізніше може зреалізувати в практичній діяльності. Участь у студентському самоврядуванні сприяє розвитку у студентів дідерських якостей, формуванню у них активної громадянської життевої позицій. Тобто діяльність студентського самоврядування в закладах вищої освіти спрямована на формування ціннісних орієнтирів молодого покоління.

Водночас студентське самоврядування - унікальний фактор реформування сучасної системи освітнього процесу в закладах вищої освіти. Здобувачі освіти активно долучаються до розробки, впровадження та акредитування освітніх програм, є експертами 3 акредитації Національного агентства із забезпечення якості освіти. У статті на конкретних прикладах продемонстровано дієвість органів студентського самоврядування у закладах вищої освіти, обгрунтовано необхідність їх розвитку як одного із чинників, що сприяє удосконаленню процесів забезпечення якості освіти.

Кдючові слова: студентське самоврядування, освітній процес, якість освіти, вища освіта, лідерство. 